\title{
ENTROPY-GUIDED PROCEDURAL SEDATION. A PROSPECTIVE, OBSERVATIONAL, MONO-CENTRIC STUDY
}

\author{
SILVIUS NEGOIȚA ${ }^{1}$, OANA TUDORACHE ${ }^{2}$, ROBERT IVAȘCU ${ }^{2}$, ALEXANDRU GRECU $^{2}$, \\ ANDRA MIRON ${ }^{2}$, DAN CORNECI ${ }^{1}$, MĂDĂLINA DUȚU ${ }^{1 *}$ \\ 1"Carol Davila" University of Medicine and Pharmacy, Bucharest, Romania \\ 2"Elias” Emergency Hospital, Bucharest, Romania
}

*corresponding author: madalinadutu236@yahoo.com

Manuscript received: March 2018

\begin{abstract}
Procedural sedation outside the operating room is more and more common. The risk of adverse events increases in parallel with the depth of sedation, therefore monitoring the level of consciousness through an objective method that accompanies clinical evaluation increases the safety of the procedure. The aim of the study was to establish an objective method of monitoring the level of consciousness in sedation and analgesia procedures. We performed a prospective, observational study, conducted in the Anaesthesia and Intensive Care Clinic of the "Elias" Emergency University Hospital, Bucharest, Romania, which included procedural sedation in the endoscopy laboratory. During the procedural sedation was registered: the sedation level evaluated both clinically via the modified Wilson scale, as well as using response entropy (RE), state entropy (SE), along with standard monitoring in procedural sedations. A statistically significant negative correlation was obtained between the two parameters of entropy and the depth of sedation $(r=-0.824$, in the case of RE, and $r=-0.804$ in case of SE). Response and state entropy values were statistically different between superficial (grades 1 and 2) and deep sedation. Entropy correlates with the depth of sedation, allowing the differentiation between superficial sedation and deep sedation. However, clear intervals of RE and SE could not be established for each degree of sedation.
\end{abstract}

\section{Rezumat}

Sedarea procedurală în afara camerei de operație este din ce în ce mai frecventă. Riscul evenimentelor adverse crește în paralel cu profunzimea sedării, prin urmare monitorizarea nivelului de conștiență printr-o metodă obiectivă care însoțește evaluarea clinică crește siguranța procedurii. Scopul studiului a fost de a stabili o metodă obiectivă de monitorizare a nivelului de conștiență în procedurile de sedare și analgezie. Am efectuat un studiu prospectiv, observațional, efectuat în clinica de anestezie și terapie intensivă a Spitalului Universitar de Urgență „Elias" din București, care a inclus sedarea procedurală în laboratorul de endoscopie. În timpul sedării procedurale a fost înregistrat: nivelul de sedare evaluat atât clinic prin scara modificată Wilson, cât şi prin utilizarea entropiei de răspuns (RE), a entropiei de status (SE), împreună cu monitorizarea standard în sedarea procedurală. O corelație negativă semnificativă statistic a fost obținută între cei doi parametri ai entropiei și adâncimea sedării $(r=-0,824$, în cazul RE și $r=-0,804$ în cazul SE). Valorile răspunsului și ale entropiei de stat au fost statistic diferite între superficial (clasele 1 și 2) şi sedare profundă. Entropia se corelează cu profunzimea sedării, permițând diferențierea dintre sedarea superficială și sedarea profundă. Cu toate acestea, intervalele clare de RE şi SE nu au putut fi stabilite pentru fiecare grad de sedare.

Keywords: state entropy, response entropy, procedural sedation

\section{Introduction}

Most of the gastrointestinal procedures are performed under sedation, thus providing greater comfort for the patient and increasing the success rate of procedures $[1,2]$.

If with regard to cardiac and respiratory monitoring, the European Society of Anaesthesiology (ESA, www.esahq.org) and American Society of Anesthesiologists (ASA, www.asahq.org) guides offer clear recommendations, in terms of establishing the level of consciousness it is suggested the continuous clinical evaluation by the physician with sedation scales (Observer's Assessment of Alertness/Sedation, Ramsay scale or the Modified Wilson scale), the use of brain activity monitoring tools remaining at the discretion of the anaesthetist [3, 4]. The risk of pulmonary complications (respiratory depression, pulmonary aspiration) increases with the depth of sedation $[5,6]$. At the same time, an inadequate sedation can cause physical and mental discomfort to the patient leading to inability to perform the procedure. The most studied brain observation tool, the Bispectral Index Monitor (BIS), introduced by Aspect Medical Systems, Inc. in 1994, the first quantitative EEG index, has not proven to be effective in differentiating sedation [7]. The absence of muscle paralysis during procedural sedation can be an explanation for failure, eye and facial muscle movements leading to false positive elevated BIS values [8]. 
Entropy (developed by Datex-Ohmeda, now part of GE Healthcare), another method of cerebral monitoring based on assessing the degree of irregularity and complexity of EEG signals has proven its effectiveness and efficiency in general anaesthesia, but there is very little information in the literature about its use in procedural sedations [9]. Unlike other brain monitoring methods, entropy comprises two parameters: state entropy (SE) that reflects cortical activity in the temporal-parietal region of the head and is scaled in 0 - 90 interval and response entropy (RE), which in addition takes into account the activity of the facial muscles. The values of RE are situated in $0-100$ interval [8]. This could be an advantage in monitoring brain activity during procedural sedation.

The aim of the study was to correlate the depth of sedation evaluated by the modified Wilson scale and by entropy and to determine state and response entropy interval ranges corresponding to sedation score.

\section{Materials and Methods}

\section{Population and study design}

The study conducted at Elias Emergency University Hospital in Bucharest was monocentric, observational, prospective, conducted over a two months period, between January 2018 and March 2018, by having the approval of the Hospital Ethical Committee. Twelve patients aged 18 to 60 years old, programmed for upper and/or lower digestive endoscopy, were included after obtaining the informed consent. The score associated to American Society of Anesthesiologist(ASA) physical status classification was 1,2 or 3 . ASA 1 means that a patient is healthy, ASA 2 refers to a patient with a mild systemic disease, and ASA 3 includes patients with severe systemic diseases that are not life threatening [10]. The exclusion criteria were: interventional endoscopy procedures, propofol allergy, neurological diseases and administration of an anxiolytic or hypnotic prior to the procedure. Patients were cardiovascular and respiratory monitored according to ESA's recommendations throughout the laboratory standby. The ECG, heart rate, and peripheral oxygen saturation were continuously recorded, and non-invasive blood pressure was measured every 2 minutes. Continuous oxygen therapy was administered via the nasal cannula with a flow of 4 liters $\mathrm{O} 2 /$ minute. To determine the entropy values, a 3-electrode sensor (GE Healthcare, Helsinki, Finland) was placed on the forehead. The interface used to report the RE and SE values, was a Carescape B450 monitor (GE Healthcare, Helsinki, Finland). During the pre-anesthetic exam, patients were informed that during the procedure they had to respond immediately to the questions asked by the physician. In case of inability to speak (e.g., upper digestive endoscopy), the patient had to lift the left thumb at the doctor's indication.
To clinically determine the sedation degree modified Wilson scale was used [11]. According to this scale 0 means that patient is awake and alert, 1 is when is minimally sedated (tired/sleepy, appropriate response to verbal conversation, and/or sound), 2 is when the patient is moderately sedated (somnolent, easily aroused wilt light tactile stimulation or simple verbal command) 3 corresponds to Deeply sedated: deep sleep, aroused only with significant physical stimulation and 4 is unarousable.

The substance used in all procedural sedations was propofol administered in boluses according to a protocol with $0.5 \mathrm{mg} / \mathrm{kg}$ initially, than $0.5 \mathrm{mg} / \mathrm{kg}$ after 1 minute, $0.25 \mathrm{mg} / \mathrm{kg}$ after another minute, $0.25 \mathrm{mg} / \mathrm{kg}$ after 2 minutes and finally $0.25 \mathrm{mg} / \mathrm{kg}$ boluses every 3 minutes until the end of the procedure.: The clinical assessment of consciousness was performed every 2 minutes, and the entropy value, response entropy and state entropy were noted immediately after the clinical evaluation.

\section{Statistical analysis}

Statistical analysis was conducted with Statistical Package for the Social Sciences (SPSS) 22 version for Windows (IBM, Armonk, NY, United States of America). For quantitative variables, the extreme values mean and standard deviation, in relation with sedation stages, have been calculated. Qualitative data have been analysed as frequency and percentage. For normal distribution variables, ANOVA analyse has been used in order to see media differences. $95 \%$ confidence interval calculation has allowed establish media difference significance. Bonferroni post hoc test has been used to analyse two sedation stages difference. For abnormal distribution variables Mann-Whitney test was used. Statistical significance has been established for $\mathrm{p}<0.05$ or $<0.01(* *)$. Normality condition was determined with Shaphiro-Wilk test $(\mathrm{p}>0.05)$. To make a correlation between sedation stages and different parameters, we used Spearmen correlation test and Pearson correlation for continuous variables. We measured entropy specificity and sensibility for sedation level diagnosis and ROC curve graphical representation.

\section{Results and Discussion}

We obtained 84 measurements in 12 patients $(50 \%$ women and $50 \%$ men) with a mean age of 49.5 years (min 38 years, max 59 years) and a median at 50 years, and an average weight of $83.9 \mathrm{~kg}$ ( $\min 54 \mathrm{~kg}$, $\max 120 \mathrm{~kg}$ ) and a median of $84 \mathrm{~kg}$.

Throughout the procedure, regardless of the sedation level, the patients were cardiovascular and respiratory stable, with no major adverse event recorded (Table I). 
Table I

Description of the main monitoring parameters

\begin{tabular}{|c|c|c|c|c|c|c|c|c|c|c|c|c|c|c|}
\hline No of Patients & \multicolumn{14}{|c|}{12} \\
\hline Sedation degrees & \multirow{2}{*}{\multicolumn{2}{|c|}{$\begin{array}{c}\mathbf{0} \\
12\end{array}$}} & \multirow{2}{*}{\multicolumn{3}{|c|}{$\begin{array}{c}\mathbf{1} \\
10\end{array}$}} & \multirow{2}{*}{\multicolumn{3}{|c|}{$\begin{array}{c}\mathbf{2} \\
27\end{array}$}} & \multirow{2}{*}{\multicolumn{3}{|c|}{$\begin{array}{c}3 \\
23\end{array}$}} & \multirow{2}{*}{\multicolumn{3}{|c|}{$\begin{array}{c}\mathbf{4} \\
12\end{array}$}} \\
\hline Measurements & & & & & & & & & & & & & & \\
\hline \multirow{2}{*}{$\mathbf{R E}$} & Min & $\operatorname{Max} \mathbf{M}$ & Min & Max & M & Min & Max & $\mathbf{M}$ & Min & Max & $\mathbf{M}$ & Min & Max & M \\
\hline & 97 & $100 \quad 98$ & 90 & 100 & 95 & 48 & 98 & 88 & 38 & 98 & 73 & 30 & 67 & 55 \\
\hline \multirow{2}{*}{ SE } & Min & Max M & Min & $\operatorname{Max}$ & $\mathbf{M}$ & Min & Max & M & Min & Max & $\mathbf{M}$ & Min & $\operatorname{Max}$ & $\mathbf{M}$ \\
\hline & 89 & 9290 & 82 & 92 & 87 & 45 & 91 & 80 & 28 & 89 & 65 & 25 & 60 & 48 \\
\hline \multirow{2}{*}{ HR, bpm } & Min & Max & Mi & & $\operatorname{Iax}$ & Min & & Iax & Min & & $\operatorname{Iax}$ & Min & & Max \\
\hline & 66 & 107 & 52 & & 06 & 55 & & 00 & 54 & & 07 & 58 & & 90 \\
\hline \multirow{2}{*}{ SBP, $\mathbf{m m H g}$} & Min & Max & Mir & & $\operatorname{Iax}$ & Min & & Iax & Min & & $\operatorname{Iax}$ & Min & & Max \\
\hline & 93 & 160 & 82 & & 45 & 75 & & 51 & 70 & & 48 & 78 & & 134 \\
\hline \multirow{2}{*}{$\mathrm{SpO}_{2}, \%$} & Min & Max & Mir & & $\operatorname{Iax}$ & Min & & Iax & Min & & $\operatorname{Iax}$ & Min & & Max \\
\hline & 94 & 100 & 92 & & 99 & 90 & & 00 & 89 & & 00 & 94 & & 99 \\
\hline
\end{tabular}

No, number; HR, heart rate; bmp, beat per minute; $\mathrm{SBP}$, systolic blood pressure; $\mathrm{mmHg}$, millimetre of mercury; $\mathrm{SP}_{2}$, peripheral capillary oxygen saturation in percent; RE, response entropy; SE, state entropy; Min, minimum; Max, maximum; M, mean
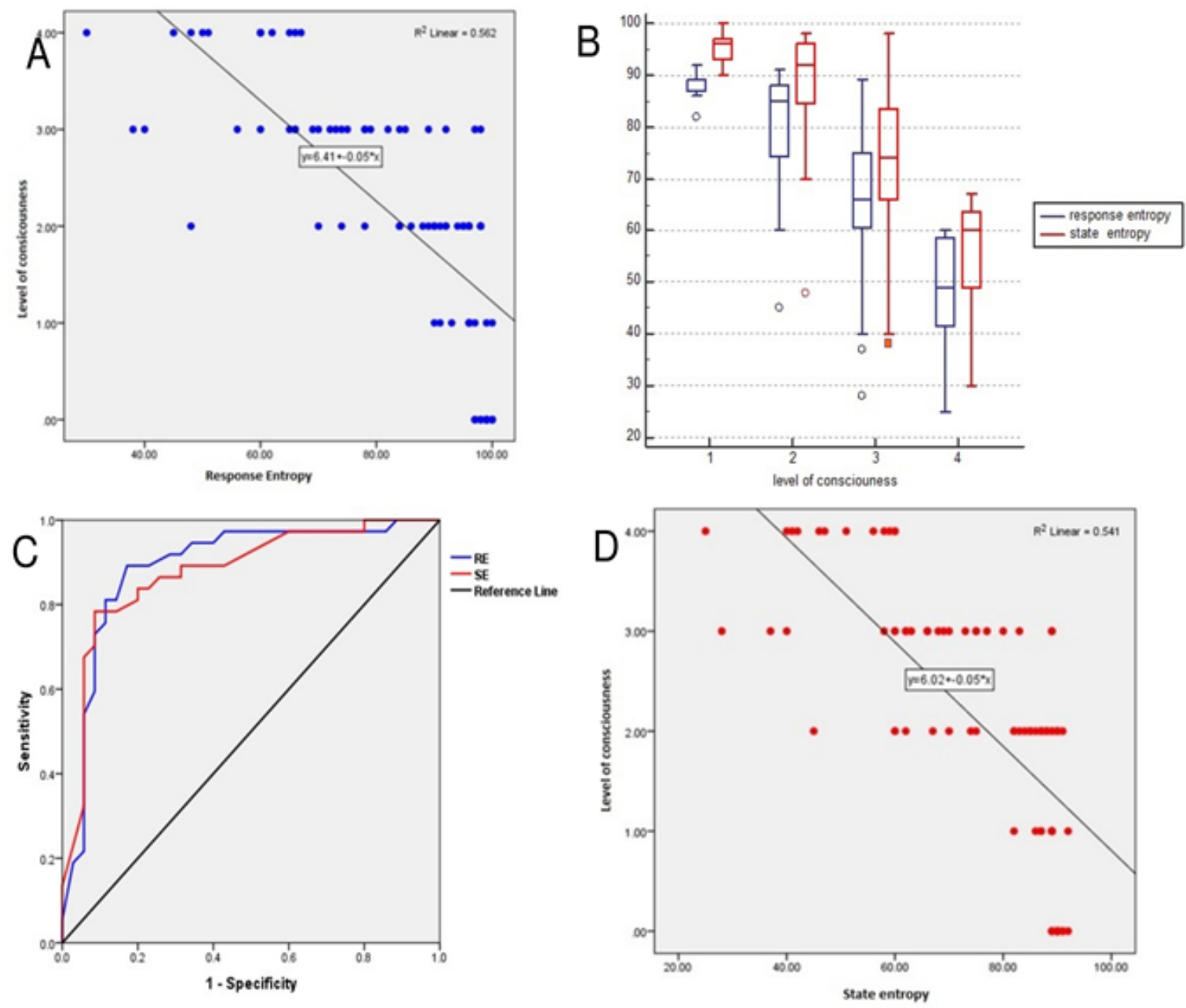

Figure 1.

Correlation between Response (A) and State (D) entropy and level of consciousness according to the Modified Wilson Scale; Response and State entropy values according to level of consciousness (B); ROC curve for SE and $\mathrm{RE}$ in diagnosis of sedation level (C)

A statistically significant negative correlation was obtained between the entropy response value and the sedation depth $\left(r s=-0.824, r^{2}=0.56, p<0001\right)$ (Figure 1A). A similar result was obtained between the state entropy value and the depth of sedation ( $\left.\mathrm{rs}=-0.808, \mathrm{r}^{2}=0.54, \mathrm{p}<0001\right)$ (Figure 1D).

The RE and SE interval values corresponding to the Wilson-modified sedation scale are presented in 
FARMACIA, 2018, Vol. 66, 6

Table I and Figure 1B. Following the ANOVA analysis, there were statistically significant differences between the RE and SE averages depending on the sedation degree. The RE and SE values corresponding sedation degrees were significantly different $(\mathrm{p}<$ 0.001). The Post Hoc Bonferoni test for multiple comparisons did not reveal statistically significant differences between incipient or deep stages of sedation ( 1 and 2 respectively 3 and 4). Significant differences of RE and SE were obtained between the incipient stage of sedation level 1 and 2 and the deep stage represented by level 3 and $4(\mathrm{p}<0.0001)$ (Tables II and III). Analysing the ROC curve and the area under the curve, for superficial sedation we obtained for RE a sensitivity of $89 \%$ and a specificity of $82 \%$, with a confidence interval between 78 and 95 and for SE was obtained a sensitivity of $78 \%$ and a specificity of $91 \%$, with a confidence interval between 77 and 94. For RE $\leq 74$ was obtained a sensitivity of $80 \%$ and a specificity of $81 \%$, with a confidence interval between 63 and 91.6 and for $\mathrm{SE} \leq 82$ was obtained a sensitivity of $82.8 \%$ and a specificity of $89 \%$, with a confidence interval between 66.4 and 93.4 (Figure 1C).

Results of Post Hoc Bonferoni test for multiple comparisons with RE as dependent variable

\begin{tabular}{|c|c|c|c|c|c|}
\hline \multirow{2}{*}{ (I) LS } & \multirow{2}{*}{ (J) LS } & \multirow{2}{*}{ Mean Difference (I-J) } & \multirow{2}{*}{ Sig } & \multicolumn{2}{|c|}{$95 \%$ Confidence Interval } \\
\cline { 5 - 6 } & & & Lower Bound & Upper Bound \\
\hline \multirow{3}{*}{1} & 2 & 5.77500 & 0.167 & -8.3001 & 19.8501 \\
& 3 & $27.09333^{*}$ & 0.000 & 12.5566 & 41.6301 \\
& 4 & $40.23333^{*}$ & 0.000 & 22.0624 & 58.4042 \\
\hline \multirow{3}{*}{2} & 1 & -5.77500 & 0.167 & -19.8501 & 8.3001 \\
& 3 & $21.31833^{*}$ & 0.000 & 9.2651 & 33.3715 \\
& 4 & $34.45833^{*}$ & 0.000 & 18.2058 & 50.7109 \\
\hline \multirow{3}{*}{3} & 1 & $-27.09333^{*}$ & 0.000 & -41.6301 & -12.5566 \\
& 2 & $-21.31833^{*}$ & 0.000 & -33.3715 & -9.2651 \\
& 4 & 13.14000 & 0.199 & -3.5139 & 29.7939 \\
\hline
\end{tabular}

* the mean difference is significant at the 0.05 level; LS, level of sedation according to Modified Wilson scale; Sig, significance level

Table III

Result of Post Hoc Bonferoni test for multiple comparisons with SE as dependent variable

\begin{tabular}{|c|c|c|c|c|c|}
\hline \multirow{2}{*}{$(\mathrm{I})$ LS } & \multirow{2}{*}{ (J) LS } & \multirow{2}{*}{ Mean Difference (I-J) } & \multirow{2}{*}{ Sig. } & \multicolumn{2}{|c|}{$95 \%$ Confidence Interval } \\
\cline { 5 - 6 } & & & & Lower Bound & Upper Bound \\
\hline \multirow{3}{*}{1} & 2 & 7.16250 & 0.312 & -8.2945 & 22.6195 \\
& 3 & $27.51333^{*}$ & 0.000 & 11.5494 & 43.4772 \\
& 4 & $40.90833^{*}$ & 0.000 & 20.9535 & 60.8632 \\
\hline \multirow{3}{*}{2} & 1 & -7.16250 & 0.312 & -22.6195 & 8.2945 \\
& 3 & $20.35083^{*}$ & 0.001 & 7.1143 & 33.5874 \\
& 4 & $33.74583^{*}$ & 0.000 & 15.8977 & 51.5940 \\
\hline \multirow{3}{*}{3} & 1 & $-27.51333^{*}$ & 0.000 & -43.4772 & -11.5494 \\
& 2 & $-20.35083^{*}$ & 0.001 & -33.5874 & -7.1143 \\
& 4 & 13.39500 & 0.281 & -4.8939 & 31.6839 \\
\hline
\end{tabular}

* the mean difference is significant at the 0.05 level; LS, level of sedation according with Modified Wilson scale; Sig, significance level

Since 2014 , the number of procedural sedations has reached about $36 \%$ of the total number of anaesthesia and sedation [10]. As the increase in hypnosis is associated with an increase in the number of complications, both respiratory and cardio-circulatory, it would be ideally to maintain the patient at a certain degree of sedation, where the risks are as small as possible and also to provide comfort to both patient and physician who perform the medical procedure. Taking into account that any clinical method of assessing the level of consciousness is subjective, the introduction of an objective method has been attempted lately.

The EEG is a way of investigating the electrical activity of the brain that has proven to be effective in monitoring sedation, showing clear modifications during sleep, sedation, and general anaesthesia [11]. Thus, the EEG represents a way of monitoring the level of consciousness that can be used to complete the clinical assessment. Currently there are 3 instruments for monitoring the depth of anaesthesia using information obtained from electroencephalogram analysis: Bispectral Index (BIS), E-entropy and Narcotrend-Compact [12]. These are recommended for all patients receiving total intravenous anaesthesia [13]. Although widely used in general anaesthesia, their benefit in procedural sedation and analgesia is controversial.

By studying BIS monitoring in continuous sedation, it was concluded that there is a strong correlation between the BIS value and the Ramsay Sedation Score (RSS), 
and that BIS allows for a more effective titration of sedatives and hypnotics [14]. Studies have also shown that the BIS value is low in what regards differentiation of sedation degrees in procedural analgesia and sedation $[7,15]$.

Unlike BIS that reflects brain activity through a single parameter, entropy, a newer monitoring method, uses in addition to electroencephalogram (EEG) also frontal electromyography (FEMG) data, thus attempting to eliminate the artifacts produced by facial muscles. Entropy has proven useful in the evaluation of hypnosis following administration of propofol, sevoflurane and thiopental [16].

Comparative studies between BIS and entropy (state entropy and response entropy) on sedation monitoring have concluded that entropy monitoring is as safe as BIS monitoring [17]. On the other hand, Haenggi M and colleagues concluded that the BIS and entropy values recorded in sedated patients cannot make the difference between sedation degrees [18].

An ideal sedative assessment tool does not exist, over time a series of subjective scores for the assessment of sedation being implemented [19]. In this study we used the modified Wilson Sedation Scale. This is quick and easy to use, showing good reliability between sedation intervals [20]. Smith and colleagues assessed the performance of Sedation Grade Indicators, suggesting a prediction probability $(\mathrm{Pk})$ calculation as an effective way to evaluate and compare the effectiveness of deep sedation indicators [21].

The first data obtained in this study show that the values of both entropy parameters are correlated with the clinical evaluation, so the increase in Wilson's sedation is accompanied by a decrease in RE and SE values. This correlates with the data found in specialized literature, Mahon and his team highlighting this in a paper published in 2008 [22].

But the most important issue in procedural sedation is to set a threshold between general anaesthesia (level 4 according to the Wilson scale) and deep sedation (grade 3 ), as the risk of lung complications increases considerably in general anaesthesia [6]. The results obtained from Post Hoc Bonferoni tests show that there can be no difference between deep sedation (grade 3) and general anaesthesia (grade 4), the mean difference being $13, p=0.199$, within the Response entropy values, and for State entropy difference being of $13, p=0.2$. Also, a clear delimitation between superficial sedation (grade 1) and moderate sedation (grade 2) cannot be made, both for RE (mean difference $=5, \mathrm{p}=0.1$ ) and for $\mathrm{SE}$ (mean difference $=7, \mathrm{p}=0.3$ ).

However, the difference between superficial sedation (grade 1) and deep sedation (grade 3) can be made, for $\mathrm{RE}$ values (the mean difference $=27, \mathrm{p}<0.001$ ) and for SE (the mean difference $=27, \mathrm{p}<0.001$ ). This is also supported by the data obtained by analysing the sensitivity and specificity of RE and SE in determining the sedation level, the RE threshold value between superficial and deep sedation being 74 and for SE the optimal value was 82 .

Kwon and his collaborators, in a study published in 2012, also attempted to assess, with the help of entropy, the depth of sedation obtained with propofol. The results were similar to those obtained in this study. It should be noted that unlike this work in which the clinical evaluation of consciousness was done using the Wilson scale, the Kwon-led team evaluated patients through the Observer's Assessment of Alertness/sedation (OAA) [23].

The limitations of the study presented are the relatively small number of patients and enrolled records.

\section{Conclusions}

In conclusion, in procedural sedations with propofol, the reduction of SE and RE values correlates with the depth of sedation (measured by Wilson scale). There are also statistically significant differences between the superficial stages of sedation $(1,2)$ and deep stages $(3,4)$, entropy monitoring making a difference between light and deep sedation. No intervals for SE and RE could be established for each degree of sedation (according to the Wilson scale). Both SE and $\mathrm{RE}$ are electroencephalographic measurements that have proven useful in monitoring general anaesthesia and are also a useful method in monitoring the depth of procedural sedation performed outside the operating room.

\section{Conflicts of Interest}

The author Robert Ivașcu is an employee of GE Healthcare, Romania as Clinical Intern. He does not declare any conflict of interest, the study being independent from the company. GE Healthcare did not offer any assistance or support for this study. The other authors have no conflict of interest to declare.

\section{References}

1. Radaelli F, Meucci G, Sgroi G, Minoli G, Technical Performance of Colonoscopy: The Key Role of Sedation/Analgesia and Other Quality Indicators. Am J Gastroenterol., 2008; 103: 1122-1130.

2. Abraham NS, Fallone CA, Mayrand S, Huang J, Wieczorek P, Barkun AN, Sedation versus No Sedation in the Performance of Diagnostic Upper Gastrointestinal Endoscopy: A Canadian Randomized Controlled Cost-Outcome Study. Am J Gastroenterol Nature Pub Group, 2004; 99: 1692-1699.

3. Hinkelbein J, Lamperti M, Akeson J, Santos J, Costa $\mathrm{J}$, De Robertis E, Longrois D, Novak-Jankovic V, Petrini F, Struys MMRF, Veyckemans F, FuchsBuder T, European Society of Anaesthesiology and European Board of Anaesthesiology guidelines for procedural sedation and analgesia in adults. Eur $J$ Anaesthesiol., 2017; 35(1): 6-24. 
FARMACIA, 2018, Vol. 66, 6

4. Practice Guidelines for Moderate Procedural Sedation and Analgesia 2018. Anesthesiology, 2018; 128: 437-479.

5. Nieuwenhuijs D, Sarton E, Teppema LJ, Kruyt E, Olievier I, van Kleef J, Dahan A, Respiratory sites of action of propofol: absence of depression of peripheral chemoreflex loop by low-dose propofol. Anesthesiology, 2001; 95: 889-895.

6. Green SM, Krauss B, Pulmonary aspiration risk during emergency department procedural sedation-an examination of the role of fasting and sedation depth. Acad Emerg Med., 2002; 9: 35-42.

7. Gill M, Green SM, Krauss B, A study of the bispectral index monitor during procedural sedation and analgesia in the emergency department. Ann Emerg Med., 2003; 41: 234-241.

8. Hernández-Gancedo C, Pestaña D, Pérez-Chrzanowska $\mathrm{H}$, Martinez-Casanova E, Criado A, Comparing Entropy and the Bispectral Index with the Ramsay Score in Sedated ICU Patients. J Clin Monit Comput., 2007; 21: 295-302.

9. Shepherd J, Jones J, Frampton G, Bryant J, Baxter $\mathrm{L}$, Cooper K, Clinical effectiveness and costeffectiveness of depth of anaesthesia monitoring (E-Entropy, Bispectral Index and Narcotrend): a systematic review and economic evaluation. Health Technol Assess NIHR Journals Library, 2013; 17: 1-264.

10. Youn AM, Ko YK, Kim YH, Anesthesia and sedation outside of the operating room. Kor $J$ Anesth Kor Soc Anesthesiolog., 2015; 68: 323-331.

11. Vernon JM, Lang E, Sebel PS, Manberg P, Prediction of movement using bispectral electroencephalographic analysis during propofol/alfentanil or isoflurane/ alfentanil anesthesia. Anesth Analg., 1995; 80: 780-785.

12. Depth of anaesthesia monitors - Bispectral Index (BIS), E-Entropy and Narcotrend-Compact M | Guidance and guidelines | NICE. NICE.

13. Smith D, Andrzejowski J, Smith A, Certainty and uncertainty: NICE guidance on 'depth of anaesthesia' monitoring. Anaesthesia John Wiley \& Sons Ltd, 2013; 68: 1000-1005.

14. Bell JK, Laasch HU, Wilbraham L, England RE, Morris JA, Martin DF, Bispectral index monitoring for conscious sedation in intervention: better, safer, faster. Clin Radiol., 2004; 59: 1106-1113.

15. Qadeer MA, Vargo JJ, Patel S, Dumot JA, Lopez AR, Trolli PA, Conwell DL, Stevens T, Zuccaro GJr, Bispectral index monitoring of conscious sedation with the combination of meperidine and midazolam during endoscopy. Clin Gastroenterol Hepatol., 2008; 6: 102-108.

16. Vakkuri A, Yli-Hankala A, Talja P, Mustola S, Tolvanen-Laakso H, Sampson T, Viertiö-Oja H, Time-frequency balanced spectral entropy as a measure of anesthetic drug effect in central nervous system during sevoflurane, propofol, and thiopental anesthesia. Acta Anaesthesiol Scand., 2004; 48: 145-153.

17. Balci C, Karabekir HS, Kahraman F, Sivaci RG, Comparison of entropy and bispectral index during propofol and fentanyl sedation in monitored anaesthesia care. J Int Med Res., 2009; 37: 1336-1342.

18. Haenggi $M$, Ypparila-Wolters $H$, Hauser $K$, Caviezel C, Takala J, Korhonen I, Jakob SM, Intraand inter-individual variation of BIS-index and Entropy during controlled sedation with midazolam/ remifentanil and dexmedetomidine/remifentanil in healthy volunteers: an interventional study. Crit Care., 2009; 13: R20: 1-10.

19. Mirski MA, Hemstreet MK, Critical care sedation for neuroscience patients. J Neurol Sci., 2007; 261: 16-34.

20. Némethy M, Paroli L, Williams-Russo PG, Blanck TJJ, Assessing sedation with regional anesthesia: inter-rater agreement on a modified Wilson sedation scale. Anesth Analg., 2002; 94: 723-728.

21. Smith WD, Dutton RC, Smith NT, Measuring the performance of anesthetic depth indicators. Anesthesiol., 1996; 84: 38-51.

22. Mahon P, Kowalski RG, Fitzgerald AP, Lynch EM, Boylan GB, McNamara B, Shorten GD, Spectral Entropy as a Monitor of Depth of Propofol Induced Sedation. J Clin Monit Comput. (Springer Netherlands), 2008; 22: 87-93.

23. Kwon MY, Lee SY, Kim TY, Kim DK, Lee KM, Woo NS, Chang YJ, Lee MA, Spectral entropy for assessing the depth of propofol sedation. Kor $J$ Anesthesiol., 2012; 62: 234-239. 